\title{
Geoarchaeology of the 18th century Qoroq shipwreck, Caspian Sea, Iran: A tale of sailing in a dynamic environment
}

\author{
Abdolmajid Naderi Beni $^{\text {a, *, Hamid Lahijani }}{ }^{\text {a }}$, Hossein Tofighian ${ }^{\mathrm{b}}$, Frédéric Guibal ${ }^{\mathrm{c}}$, \\ Keivan Kabiri $^{a}$, Timmy Gambin ${ }^{\mathrm{d}}$, Morteza Djamali ${ }^{\mathrm{c}}$, Hamidreza Abaie ${ }^{\mathrm{e}}$, Vali Jahani ${ }^{\mathrm{f}}$ \\ ${ }^{a}$ Iranian National Institute for Oceanography and Atmospheric Science (INIOAS), No. 3, Etmadzadeh Street, West Fatemi Avenue, Tehran, Iran \\ ${ }^{\mathrm{b}}$ Research Institute of Cultural Heritage and Tourism (RICHT), 30 Tir Street, Imam Khomeini (RA) Avenue, Tehran, Iran \\ ${ }^{\mathrm{c}}$ Institut Méditerranéen de Biodiversité et d'Écologie Marine et Continentale (IMBE), IMBE - UMR Aix Marseille Université, CNRS, IRD, Avignon Université, Malta \\ ${ }^{\mathrm{d}}$ Department of Classics \& Archaeology, University of Malta, Msida, Malta \\ e Guilan's Ports and Maritime Administration, Anzali, Guilan Province, Iran \\ ${ }^{\mathrm{f}}$ Administration of Cultural Heritage, Tourism and Handicrafts of Guilan Province, Rasht, Guilan Province, Iran
}

\section{A R T I C L E I N F O}

Keywords:

Sea-level change

Caspian Sea

Shipwreck

Geoarchaeology

Sediment

History
A B S T R A C T

\begin{abstract}
Despite frequent historical documents on shipping and trade routes in the Caspian Sea since early historical dates, the maritime archaeological evidence remains largely undiscovered. Exposing a shipwreck in southwest corner of the Caspian Sea at the shoreline of Qoroq village in Guilan Province of Iran provides an opportunity to study some frames of historical maritime activities in southern Caspian coasts. Sedimentological and geophysical, archaeological, and historical investigations were conducted to detect the age of the shipwreck, its probable origin and the impacts of environmental changes on preservation, exposing and damaging the ship. The results showed that the ship was broken down along its longitudinal axis and the remains were distributed along the shore where they are buried by coastal sediments. Pinus sylvestris is the tree species used in building the ship and the Caucasus Mountains was considered as a timber supply area. A combination of radiocarbon data and historical evidence showed that the ship's construction date is mostly back to mid-18th century. It seems that the ship sunk in a high energy environment. Deposition of various types of sediments inside and around of the shipwreck suggests that the ship was dragged from the high energy environment to the current location. The hydrodynamics of the coastal area along with rapid Caspian sea-level changes were mostly responsible for preservation as well as exposing the ship.
\end{abstract}

\section{Introduction}

The Caspian Sea lies at the border of Europe and Asia surrounded by Russia, Azerbaijan, Iran, Turkmenistan and Kazakhstan. In spite of ample historical references to shipping and trade routes in the Caspian Sea, the maritime archaeological evidence remains largely unexplored. Overall, this could be related to scarcity of the archaeological exploration of the Caspian Sea (Okorokov, 1993) and also possibly due the exceptional natural condition of the sea and the coastal areas.

Some form of early underwater archaeological investigations in the area dates to the first part of the 19th century, which was conducted by Russian authors. Systematic investigation on submerged monuments was initiated by Azerbaijan Academy of Sciences in 1933 in coastal waters of Baku (Okorokov, 1993). More investigations were executed in the 1960s, these resulted in with the exploration of medieval settlements in the Kura River mouth in Azerbaijan (Okorokov, 1993). In 1982, the remains of an early 19th century ship containing Russian Army treasury was discovered in Bay of Baku (Okorokov, 1993). Systematic underwater archaeology off the Iranian coast of the Caspian Sea, however, has not yet begun. Some sporadic works have been conducted in the framework of land based archaeological excavations in Iran by Chaichian (2014) and Nokandeh et al. (2006). Moreover, some reconnaissance studies have been launched by the Research Institute of Cultural Heritage and Tourism (RICHT) based on reports related to shipwrecks or artifacts in Iran's coastal waters (Tofighian and Adibi, 2017).

\footnotetext{
* Corresponding author.

E-mail address: amnaderi@inio.ac.ir (A. Naderi Beni).
} 


\subsection{Recent developments}

Over the last two decades, the sea-level of the Caspian Sea has been dropping. This process has brought to light some historical ships in Iranian coastal areas such as the Qoroq, Amirabad-e- Lahijan, Neka and Langeroud (Tofighian and Adibi, 2017) and more recently in Astara, in Guilan Province (Fig. 1). The fragile wooden ship elements are prone to damage and destruction by wave action as happened with the Neka shipwreck (Tofighian and Adibi, 2017). However, the Qoroq wreckage is still intact and well-preserved thus making it possible to save. In the light of this, the Ports and Maritime Administration of Guilan Province, Iran, has provided financial support for a collaborative project together with the Iranian National Institute for Oceanography and Atmospheric Science (INIOAS), the RICHT and Administration of Cultural Heritage, Tourism and Handicrafts of Guilan Province to explore on the feasibility of saving the Qoroq shipwreck.

Historical documents show that the Qoroq area in the southwest corner of the Caspian Sea was not a permanent major harbor/port in the Caspian Sea. However, repeated reports by the area's inhabitants of wrecks and cultural material such as ceramic fragments datable to late antiquity point to a level of maritime activity that certainly deserves a more in-depth study. In this context, there are number of pertinent research questions that must be asked:
1) Is the archaeological material an in-situ primary deposit or is it being washed in by waves and currents?

2) What is the origin of the ship?

3) Where was the ship built?

4) How did the ship sink?

5) What is the impact of the environmental changes (e.g. sea-level changes) on the site?

This article seeks to answer the aforementioned questions, through the use of a variety of approaches and techniques including geology, geoarchaeology, history, remote sensing and xylology.

\section{Geographical setting}

The Caspian Sea is the largest enclosed water body in the world and presently stands at $28 \mathrm{~m}$ below mean sea-level (msl). Since the Last Glacial Maximum, the sea-level has fluctuated between $113 \mathrm{~m}$ above present $\mathrm{msl}$ to less than approximately $50 \mathrm{~m}$ below msl (Chepalyga, 2007) and continued to fluctuate between 19 and $29 \mathrm{~m}$ below msl during the last 2500 years (Naderi Beni et al., 2013a). From 1929 to 1995, the Caspian Sea has experienced a full cycle of regression-transgression of about $3 \mathrm{~m}$ (Kroonenberg et al., 2000) and has been in a declining trend since 2007 after around ten years of high-stand (Lahijani et al., 2019).

The Sea runs along a north-south axis and is approximately $1200 \mathrm{~km}$
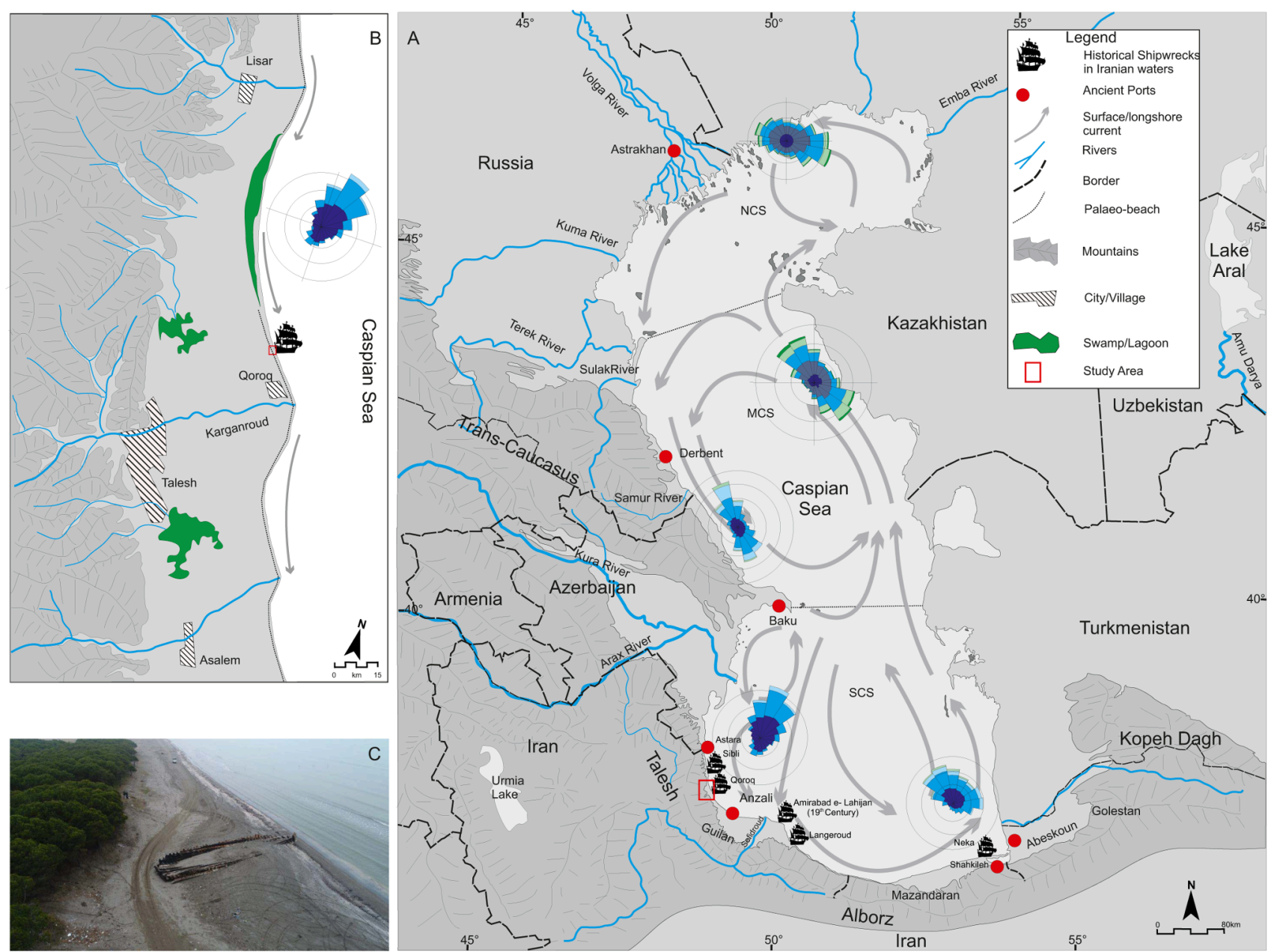

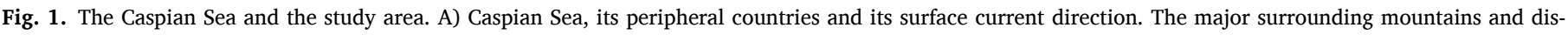

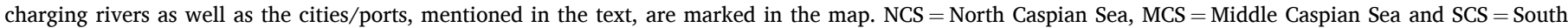

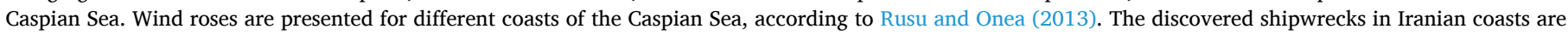

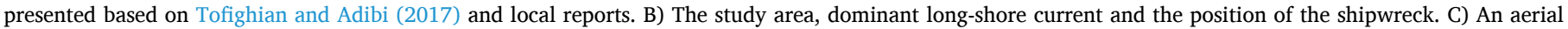
photo of the Qoroq shipwreck that was taken in 2018. 
in length with a width of about $325 \mathrm{~km}$. Hydrographically, the sea could be divided into three distinctive parts (Fig. 1); The North Caspian Sea is characterized by shallow water with an average depth of $4 \mathrm{~m}$. The central part of the sea approaches depths of $800 \mathrm{~m}$, and the Southern Caspian Sea is the deepest part with depths of more than $1000 \mathrm{~m}$ (Terziev, 1992).

The enclosed water body is characterized by its brackish water and tide free nature (Ghaffari and Chegini, 2010). Depending on the season, the dissolved oxygen of surface waters of the south Caspian Sea ranges between 7 and $11 \mathrm{mgl}^{-1}$ (Tuzhilkin et al., 2005). However, this is highly variable in coastal waters due to riverine impacts, variation of temperature and wave breaking. The $\mathrm{pH}$ values of the Caspian waters are greater than the open seas due to the rivers' input that is characterized by high content of anions of weak acids (Tuzhilkin et al., 2005). The greatest $\mathrm{pH}$ values in the Caspian Sea belong to surface layer of the water at rivers' mouth areas in summer time (Tuzhilkin et al., 2005).

Caspian sea-level changes heavily impact all characteristics of the sea especially in coastal areas. During sea-level fall, the coastal sediments experience processes of salinization and weak accumulation of humus. During sea-level rise and the formation of lagoon environments in gently slope coasts, sulfides and humus are accumulated and gleyzation takes place (Kasimov et al., 2012).

The climate of the Caspian Sea is mainly governed by the Siberian High, Westerlies and Arctic polar air masses (Lahijani et al., 2016). Three main seasonal weather systems each locally influenced by the orography (West and Northwest, East and Northeast and SouthSoutheast) dominate the Caspian region (Lahijani et al., 2016; Rusu and Onea, 2013). Two predominant seasonal wind directions blow over the Caspian Sea. Northerly winds (north, northeast and northwestern) are frequent throughout the year, but are more dominant in summertime. Southerly winds (mostly southeasterly winds) are more frequent in winter and spring (Kosarev, 2005).

The number of stormy days in the Caspian Sea largely differs according to geographical positions (Kosarev, 2005). While the number of stormy days on the coastal areas of the northern and eastern areas reaches 40 days per year, the western coast (especially the coast of Azerbaijan) is stormier with approximately 60 stormy days per year. On the other hand, the southern coast is the calmest with a maximum of 30 stormy days per year. In the wintertime, the coast of Azerbaijan is prone to receive the greatest waves from the northerly storms (Baku Nord) and wave height can reach up to $8 \mathrm{~m}$ and even 9-10 $\mathrm{m}$ during extreme events (Kosarev, 2005). Because of shallow water depths and the flat topography, the eastern and northern coasts of the sea do not experience high waves, instead, they are intensively impacted by storm surges (Kosarev, 2005).

General surface currents of the Caspian Sea run anticlockwise (Fig. 1); starting from the north due to the flow of freshwater from the Volga River into the Sea. On the other hand, the southeastern area of the sea experiences a high evaporation rate. As a result, the general counterclockwise run of the surface currents is mainly governed by the density gradient in the two opposite sides of the sea (Ibrayev et al., 2010). However, currents in the Caspian Sea are more complicated due to the action of seasonal winds and atmospheric forces which combine with different types of density currents (Gunduz and Özsoy, 2014). As a result, the current, in terms of speed and direction, differs in various depths depending on the geographical position and seasonal changes (Gunduz and Özsoy, 2014).

\subsection{The Qoroq shipwreck}

The Qoroq shipwreck was first identified in 2005 in the southwest corner of the Caspian Sea, in an area known as Talesh (Hashtpar) and at the northern flank of Karganroud delta which drains the Kargan River (Fig. 1). The submerged shipwreck was initially reported by fishermen whilst still underwater. It was completely exposed in 2013 when the sealevel dropped. Recently, another wreck has been reported at a depth of
$5 \mathrm{~m}$ in an area north of Qoroq in Astara (Fig. 1A). One other wreck has been noted just a few hundred meters south of the Qoroq shipwreck.

The study area is characterized by a narrow coastal plain that is delimited by the sea on one side and the high Talesh Mountains on the other side (Fig. 1). The seabed is characterized by a gentle topography with water depths of up to $10 \mathrm{~m}$ stretching as far as $5.5 \mathrm{~km}$ offshore. The shipwreck is located between two rivers, Lisar to the north and Karganroud to the south. Boulder and gravelly deposits are brought by the rivers during flash floods. In turn, these deposits form relatively symmetric deltas (Fig. 1). A lagoon environment, fed by precipitation and irrigation waters, has been formed between the two deltas (Fig. 1B). The Qoroq wreck is located $3 \mathrm{~km}$ north of the Karganroud river mouth, $2 \mathrm{~km}$ south of the lagoon and $10 \mathrm{~km}$ south of Lisar River's mouth and near the lagoon.

The Qoroq beach is mainly covered by medium to coarse sand whereas at the Karganroud and Lisar rivers mouth sediments are coarser grain. For instance, pebbles make up around $76 \%$ of the Karganroud River mouth's deposits (Table 1, Bagheri, 2017).

\section{Material and methods}

\subsection{History}

Firstly, a desk-based study was undertaken with an emphasis on historical documents related to shipping and navigation in the Caspian Sea. Based on the initial estimates of the ship's age, special focus was devoted to the maritime activity of recent centuries. Historical study was conducted on the basis of published sources. This study was followed up with an archaeological survey as well as interviews with locals. Each phase contributed to the gathering of a more comprehensive body of information related the shipwreck.

\subsection{Excavation}

Uncovering the ship for any length of time would almost certainly lead to the destabilization of the structure and expose the fragile wood to destructive coastal processes (Curci, 2006). The authorities issued a fiveday permit for the limited removal of the sediments to expose parts of the shipwreck to prevent any destabilization of the structure. Following the operation, the shipwreck was to be immediately reburied. Due to these restrictions, the excavation plan was limited to 6 test trenches around various areas of the ship (Fig. 2). The central area of the shipwreck was highlighted for excavation as it was the most likely area that would contain artifacts that could shed light on the identity and typology of the ship. It was estimated that around 80 tons of sediment would have to be displaced and enough tools and manpower were therefore organized for the operation.

As can be deduced from Fig. 2 A, the continual infiltration of sea water into the beach sediments did not permit the excavation of more than $20 \mathrm{~cm}$ for the $2 \mathrm{nd}$, 3rd and 4th test trenches. Moreover, the 6th trench was removed from the plan as it would have inconvenienced local inhabitants. So, the test trenches were limited to areas 1 and 5 (Fig. 2 B). The sampling and documentation of the shipwreck was based on recommendations of Maarleveld et al (2013). As per permit requirements, the trenches and uncovered areas were reburied immediately.

\subsection{Ground penetrating radar}

To see any probable buried coastal infrastructures or any detectable underground objects related to the ship, an unshielded Mala Geoscience Ground Penetrating Radar (GPR) was used to survey the surrounding sediments before the excavation. A $200 \mathrm{MHz}$ antenna was selected to get the highest possible resolution and penetrating depth. ReflexW software was used for processing of the paralleled profiles to get an integrated image of the subsurface. Standard processing steps (DC shift, gain function and band pass filtering) were utilized on the GPR data to get the 
Table 1

Sediment type of the Caspian shoreline in the study area (Bagheri, 2017).

\begin{tabular}{|c|c|c|c|c|c|c|c|}
\hline Location & Pebble (\%) & Very coarse sand (\%) & Coarse sand (\%) & Medium sand (\%) & Fine sand $(\%)$ & Very Fine sand (\%) & Mud (\%) \\
\hline South of Karganroud River mouth & 76.64 & 14.85 & 7.6 & 0.27 & 0.04 & 0 & 0.6 \\
\hline North of Karganroud River mouth & 39.95 & 18.3 & 28.92 & 12.27 & 0.22 & 0.09 & 0.26 \\
\hline South Of Qoroq & 0 & 18.87 & 64.23 & 11.07 & 5.49 & 0.33 & 0 \\
\hline Qoroq & 0 & 6.26 & 50.19 & 31.77 & 9.61 & 1.19 & 0.97 \\
\hline South of Lisar River Mouth & 0 & 16.41 & 8.4 & 21.61 & 48.75 & 4.71 & 0.13 \\
\hline
\end{tabular}
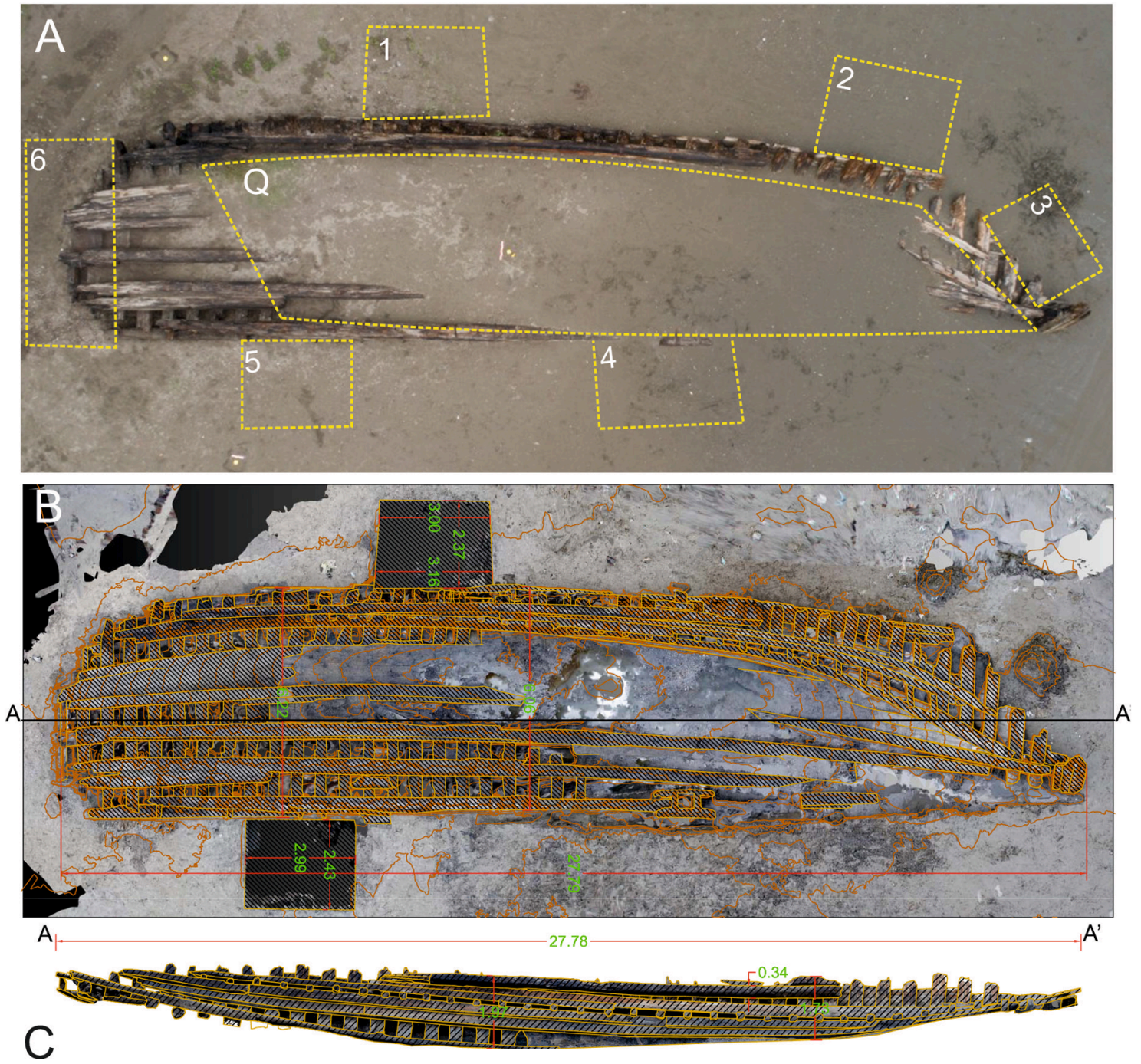

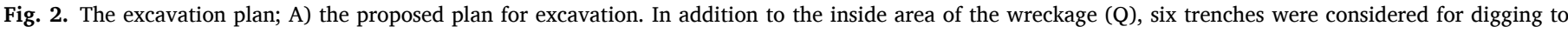

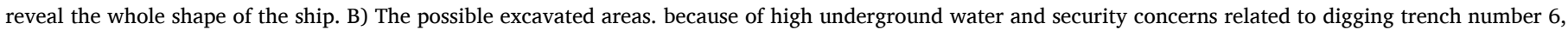
only the 1 th and 5 th trenches and the inside area (Q) were possible foe working. C) The profile of the shipwreck (The measurements are in meter).

best subsurface images (Neal and Roberts, 2000).

\subsection{Remotely sensed data}

Different types of satellite images (e.g. Landsat series, Ikonos, QuickBird, and WorldView-2) between 1975 and 2019 were used to track the local shoreline changes and/or any changes in the position of the wreckage.

\subsection{Photogrammetry}

Time constraints required a quick and accurate recording methodology. Imagery for 3D photogrammetry and site documentation was obtained with a Canon 5D DSLR camera and a DJI Phantom 4-Pro drone. Miras-e Arka Corporation were sub-contracted to undertake this part of the operation. The photos were combined to make an integrated 3D image of the ship using Bentley's ContextCapture software.

\subsection{Wood sampling}

A piece of wood was removed from the ship's hull and sent to the Poznan Radiocarbon Laboratory (PRL) for radiocarbon age dating. Due to possible contamination with oil, any hydrocarbon residual was removed by PRL before dating ( $T$ Goslar, pers. comm.). The obtained age $(235 \pm 30)$ was calibrated using IntCal13 calibration curve (Reimer et al., 2013) in 'Bchron' package (Haslett and Parnell, 2008) run in 
RStudio (RStudio Team, 2015).

Moreover, wood samples of 5-10 cm3 were taken from two parts of the ship's hull for xylological analysis. Microscopic examination was conducted in Mediterranean Institute of Biodiversity and Ecology of Marine and Continent (IMBE) in France. Radial, tangential and transverse thin sections were prepared by hand for each sample by using a razor blade. The sections were immersed in water, mounted on glass and observed immediately by means of transmitted light microscope (Olympus CX41 40x-1000x). The anatomical characters observed allowed the identification of the taxa by comparison with wood atlases (Jacquiot, 1955; Schweingruber, 1982, 1990).

\section{Results}

\subsection{History}

Although the Caspian Sea was well known by the early geographers and historians (Ahrari, 1996; Herzfeld and Walser, 1968) little evidence was forthcoming for maritime activity until the emergence of Islam in the region. This is possibly due to the rough seas and its distant position relative to the great centers of civilizations (Tarn, 2010). At least until mid-17th century, navigation on the Caspian Sea was restricted to summer time (Olearius, 1656) and the majority of the trade was conducted by Muslim ships. Compared to contemporary Mediterranean ships, Muslim crafts were relatively small in size (Danişman, 1970).

Since the 8th Century, the southeastern corner of Caspian Sea was the main hub for a major trade route established between Abeskoun to Darband (Fig. 1 A; Naderi Beni et al., 2013a). During the Safavid dynasty of Iran (1501-1736 CE), ports in southeastern Caspian Sea e.g. Shahkileh (Fig. 1A) were major trading centers with connections to the Darband at the middle Caspian coast (Naderi Beni et al., 2013a). However, in 19th century the focus of trades gradually migrated westwards where Anzali (Fig. 1A) evolved into the major port. This was due mainly to the Guilan's silk trade, global geo-political changes and the rise of European powers, especially the Russian domination of the Caspian Sea (Nagdaliev, 1976).

Russian penetration into the Caspian Sea started in the early 17th century by the development of a port and a shipyard in Volga tributaries in Astrakhan (Bennigsen and Berindei, 1979). The systematic development of maritime activities by Russia in the area was accelerated in the early 18 th century with the preparation of the first nautical charts of the Caspian Sea. Moreover, new shipyards in Astrakhan (Fig. 1A) manufactured 38 ships of 150-200 tons of capacity to trade with the southern Iranian coasts (Hanway, 1762). In the mid-18th century, British merchants committed to establish a shipyard in Langeroud on the Iranian Caspian coast (Fig. 1A). Several ships were built including armed vessels ordered by the Afsharid Persian king. However, shipbuilding in the yard was brought to an end because of Russian interference and the assassination of the British merchant by rebels in 1751 .

Navigation in 19th century was dominated by the absolute supremacy of Russia in the Caspian Sea (Nagdaliev, 1976). The development of new shipyards and ports was supplemented by marine transportation services including postal services and passenger facilities. Regular trade routes between Iran and Russia saw Anzali evolve as the main port of Iran on the Caspian Sea. On the other hand, Baku and Astrakhan were the main centers in new Russian territory acquired after victories by the Russians in its wars with Iran (Nagdaliev, 1976). During two successive wars between Russia and Iran in 1804-1813 and 1824-1826, Iran lost the right to build and deploy armed vessels and heavy ships in the Caspian Sea. Its use of the sea was therefore severely restricted (Nagdaliev, 1976). After the wars, Russian ships were conducting the majority of trade in the Caspian Sea - transporting petroleum, wood, and other manufactured products (Nagdaliev, 1976). According to Curzon (2007), in 1878 more than 1200 wooden sailing ships and around 790 steamships were operating in the Caspian Sea. In 1904, the Russian government passed a law encouraging ship owners to replace wooden ships with metal ones (Nagdaliev, 1976).

Although there are some reports on traditional ship building in Anzali in 1822 (Fraser, 1826), the industry was mainly limited to the construction of flat-bottomed boats (Karaji) for unloading operations and local shipping (Bazin, 1974). A type of round ship, similar to a Karajies, was constructed by Turkmens and was known as Nav. This type of boat measured approximately $25 \mathrm{~m}$ in length and $4 \mathrm{~m}$ beam. It was mainly used for trade between Turkmenistan and Anzali by coastal sailing (Bazin and Bromberger, 1982).

In addition to Anzali, other less important ports/harbors including Karganroud, Haviq and Astara were developed to the west of Anzali and were used for minor trade routes (Fig. 1A). Rabino (1917) mentioned that Russian merchants brought their manufactured merchandise to exchange mainly for wood, food and charcoal in the auxiliary ports. According to Khodaverdi (2008), the port of Karganroud was mainly used for the timber trade conducted with Russian merchants. Different types of timber (e.g. maple, oak, elm, plane trees, alder and especially walnut and boxwood trees) were transported by steamships (Prokhod) from Karganroud to Baku and then exported to other European countries including Britain (Bazin, 1974). The over-exploitation of woodlands led to a dramatic decrease of the resource and the eventual extinction of natural boxwood forests in Talesh (Curzon, 2007). Historical reports (Rabino, 1917), point to the coastal village of Haviq, $30 \mathrm{~km}$ north of Karganroud, as Talesh's main harbor before the development of Lankaran in Azerbaijan. Fisheries in the Karganroud area were leased by the government of Iran to Lianozov, a Russian company. It created a fishing port in Lisar (Rabino, 1917).

Some historical reports were found about ship landing/sinking in coastal area of Iran (Fig. 3) that were mostly related to Stenka Razin rebellion in the mid-17th century (Stepanov, 1957) and Russia-Iran wars in the early-19th century (Khodaverdi, 2008).

\subsection{Reconnaissance surveys}

A large piece of a broken hull from a wooden ship, very similar to the main shipwreck, was found $500 \mathrm{~m}$ south of the Qoroq shipwreck on top of a sandy coastal escarpment. The wreckage is covered by $30 \mathrm{~cm}$ of coastal windblown sand (Fig. 4) and lies on a sediment sequence containing evidence of a major palaeo-beach and two minor ones from the last sea-level rises (Fig. 4). The sedimentary outcrop at the base shows approximately $40 \mathrm{~cm}$ of alternation between shell layer and medium sized sand. The alternation is succeeded by an around $40 \mathrm{~cm}$ of a medium sized sand layer containing shell debris that shows layering. The top of the outcrop is covered by less than $40 \mathrm{~cm}$ of wind-blown coastal sand. According to interviews with the locals, the wreck was exposed in 2018 during the excavation of a channel for aquacultural activity. The locals also mentioned that the authorities tried to displace the Qoroq wreckage using a mechanical excavator and loader with the intention of putting it on public display. This attempt was however unsuccessful. It was also stated that no objects related to the ship's cargo (or otherwise) were found during the operation.

\subsection{Excavation and documentation}

Subsequent excavations exposed the shipwreck, which had been broken into half along its longitudinal axis (Fig. 5A). The remaining part measures $27.79 \mathrm{~m}$ in length with a width of $6.22 \mathrm{~m}$ at its widest (Fig. 2). The preserved frame of the ship is composed by 42 elements. Planks are fastened to the frames with metal nails (Fig. 5D). Six elements of the ceiling (stringers) are also identified. The mast step, which served to house the foot of the mast, is preserved. A number of elements of axial carpentry are preserved: keel, stem, and sternpost.

A large square hole with a $40 \mathrm{~cm}$ diameter is evident on the northern part of the ship where the wooden planks of the hull exist (Fig. 5E).

Inside the shipwreck, sediments do not contain any cultural material but layering can be observed. There are three main sediment layers 

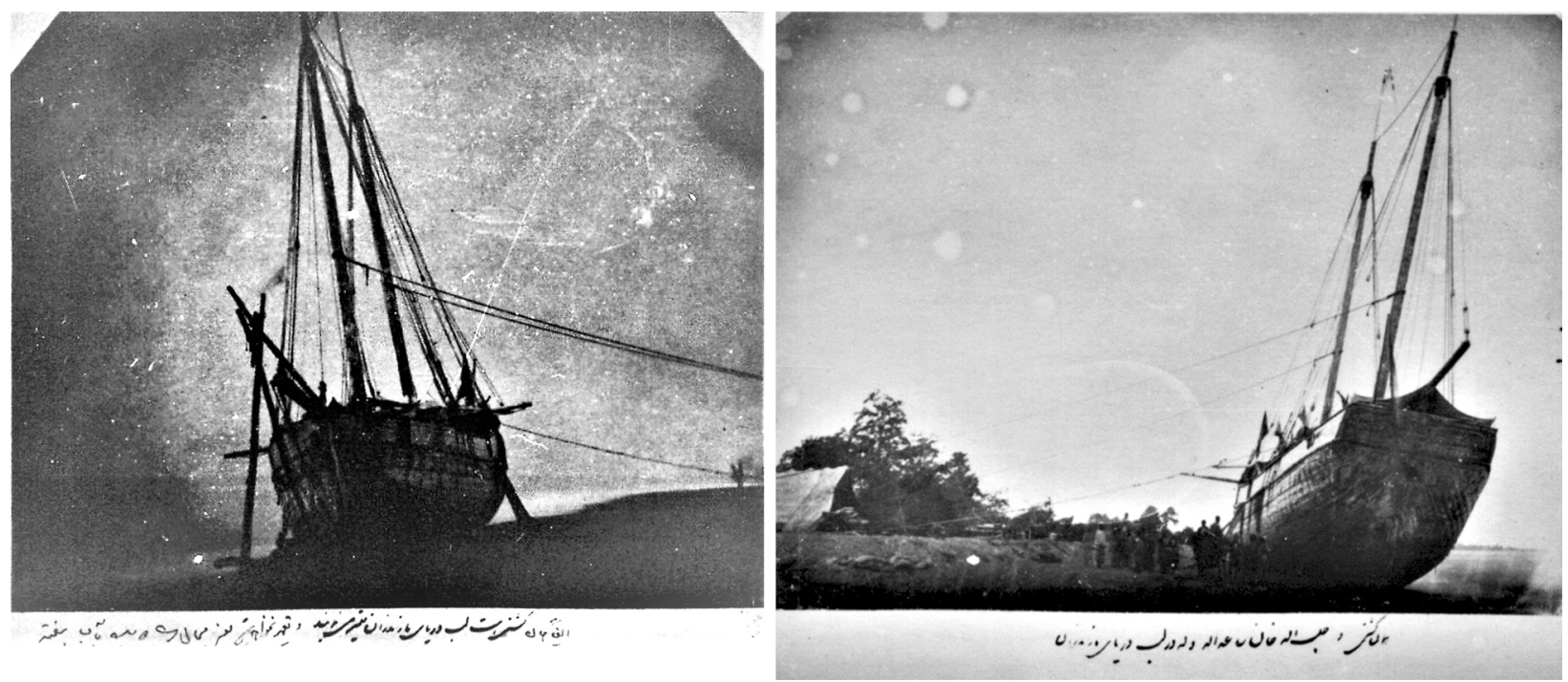

Fig. 3. A grounded ship in Iranian Caspian coast in 1880s. The ship owned by Habib-Allah-Khan, a local governor of Astarabad, southeastern Caspian city. The right photo is captioned as "the ship and Habib-Allah-Khan e Sa'ed Al-Dowleh at the shoreline of Mazandaran (Caspian) Sea". The left photo is the same ship that is captioned as "the same ship at the shoreline of Mazandaran Sea that is being repaired. It will not be repaired; it means that it will not be lunched into the sea" (by courtesy of the Ports and Maritime Organization).

(Fig. 6). The uppermost layer consists of brown loose sand containing leaves, wood debris, plastic and cans that were deposited in recent years. The middle layer is separated from the overlaying recent deposits by a thin layer of shell and shell debris. It consists of grey fine to medium sand that covers the base semi-consolidated gravelly layer. The gravelly layer is semi-consolidated and is cemented occasionally to the ship's floor. Gravel is well rounded with a maximum diameter of up to $10 \mathrm{~cm}$.

\subsection{Xylological analysis}

Two wood samples were analyzed and both were identified as Pinus sylvestris (Fig. 7). This refers either to Pinus sylvestris L. (Scots pine), Pinus nigra Arnold. (Black pine) or Pinus uncinata Ramond (Mountain pine) which all have similar wood anatomical features.

\subsection{Radiocarbon age dating}

The uncalibrated radiocarbon date from said samples is $235 \pm 30$ before present (BP). However, the calibration of the result using Intcal13 Database shows several peaks with different probabilities (Fig. 8). The most probable dates for the cutting the trees are to 1634-1682 CE and $1762-1803 \mathrm{AD}$, with $49.3 \%$ and $33 \%$ of probability, respectively. The 17th century calibrated age dovetails with the Safavid dynasty in Iran while the 18th-19th century dates fall in Afsharid and Zand kingdoms in Iranian territory (Fig. 8).

\subsection{Satellite image processing}

The results of satellite image processing show that the shoreline was repositioned approximately $150 \mathrm{~m}$ since 1975 , so that the sea-level was in lowest position in 1975 and in highest position in 2010 (Fig. 9). Satellite images show the shipwreck was already identifiable in 2004 and was completely exposed in 2018 . No detectable change in the position of the shipwreck was recognized.

\subsection{Ground penetrating radar (GPR)}

GPR results show that the sediments on the northern side of the shipwreck are continuously deposited without any interruption. However, GPR profiles on the southern side of the shipwreck show some reflectors that are interrupted by changing their direction landward and/or abruptly cut into segments. These changes are limited to depths of between $4 \mathrm{~m}$ and $7 \mathrm{~m}$ (Fig. 10) and are distributed from approximately $10 \mathrm{~m}$ south of the shipwreck up to $30 \mathrm{~m}$ further to the south (Figs. 11 and 12). It seems that some solid objects are present in the anomalous area, as the sedimentation pattern is different in both sides of the objects (Fig. 10).

A 3D image of the subsurface was prepared and sequential horizontal slices were processed by the software to observe potential changes at the subsurface. The images corroborate the observations from the $2 \mathrm{D}$ profile. It seems that some objects are distributed along the shore. The biggest subsurface anomaly measures $8 \times 4 \times 3 \mathrm{~m}$ that is elongated along the shoreline and is in close proximity to smaller anomalies (Fig. 12).

\section{Discussion}

According to xylological results three pine species could be attributed to the material used to construct the ship. As the Pinus nigra distribution area is limited to the circum Mediterranean region and the Pinus uncinata to western and central Europe, it is probable that Pinus sylvestris was used in the ship building. This species has a very wide distribution area through Europe that has a larger natural range than any other pine in the world, spanning northwards from Spanish Sierra Nevada to Arctic Norway, and eastwards from Atlantic Scotland to almost the Pacific coast of Siberia (McLean 2019). Although its timber is not very durable, Pinus sylvestris and Pinus nigra have good physical properties and are both considered as usable in shipbuilding. Considering the Qoroq shipwreck location we hypothesize Pinus sylvestris as the tree species used and the Caucasus Mountains as a timber supply area.

The calibrated age for the Qoroq Shipwreck shows with a $49.3 \%$ degree of certainty, the ship was built in mid-17th century (Fig. 7). However, historical documents do not support this date for the ship. Apart from Stenka Razin raids on the southern shores of the Caspian Sea (Roberts, 1965), Russian merchants in 17th to early 18th centuries rarely traded on the southern coasts with their navigation limited to Darband in the Middle Caspian Sea (Hanway, 1762). Moreover, we have not found any historical evidence for the development of shipyards in Iranian territories of Caucasus datable to the 17th century and with capability of building large heavy ships.

On the other hand, the calibrated age date with a 33\% rate of 

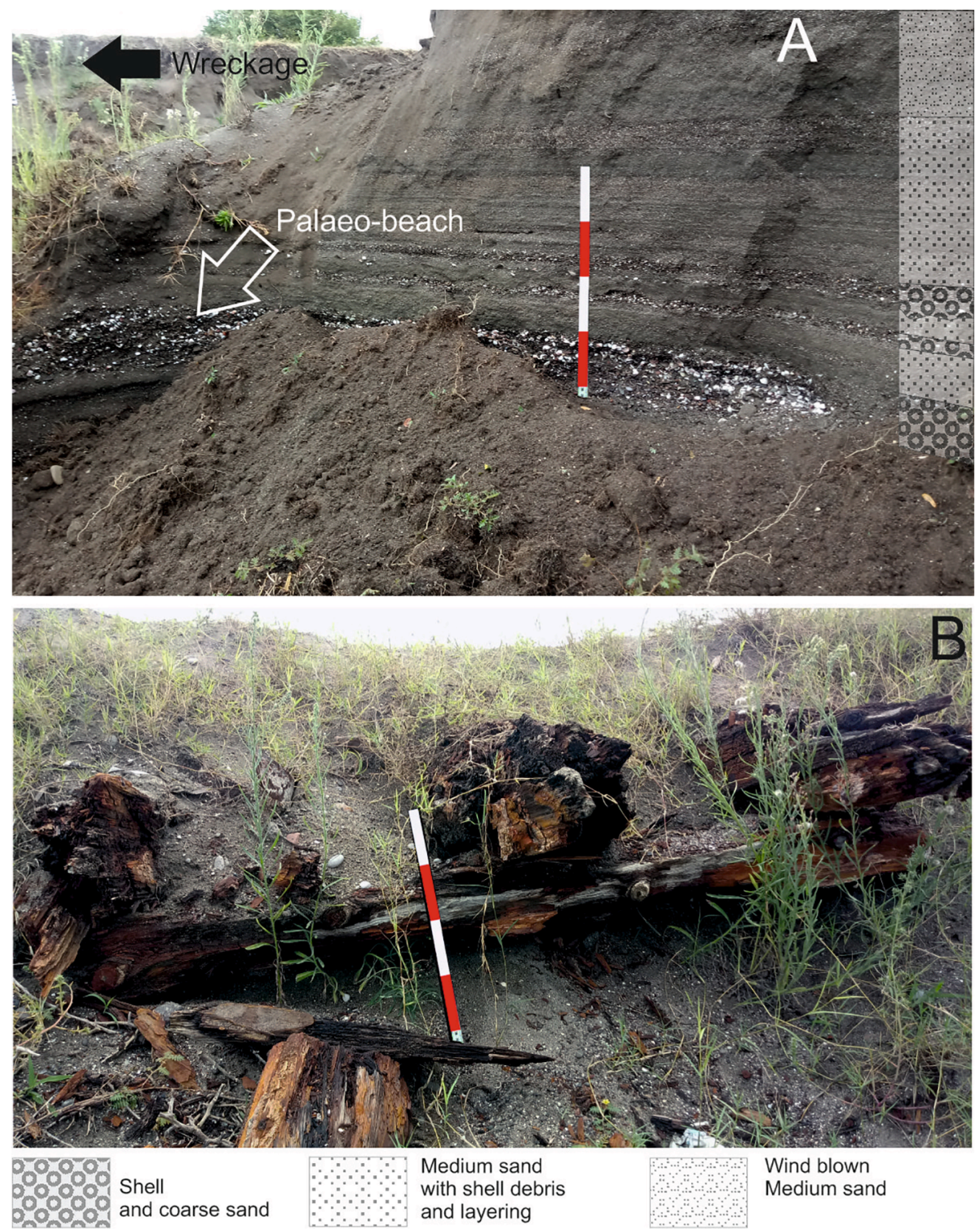

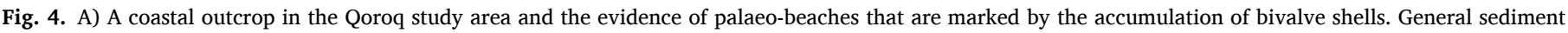

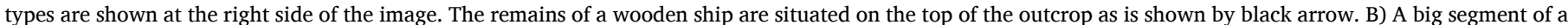
hull on top of a coastal escarpment.

certainty suggests that the ship was built sometime between 1762 and $1803 \mathrm{CE}$. These dates are supported by historical documents and are hence more realistic. In 1735 some shipyards were opened by Russia in the Volga River and regular trade was established between Astrakhan and Guilan. More than 30 ships with the capacity of 150 to 200 tons were conducting trade with the Persian Empire (Hanway, 1762). The commercial and military rivalries between Iran and Russia in the Caspian Sea made the king of Iran to develop new shipyards in Guilan's coast in 1742 in collaboration with British merchants but it was stopped in 1751 (Hanway, 1762; Curzon, 2007). As Curzon (2007) mentioned, the Iranian ships were built from wood available in Iran's forests. However, pine trees are absent in Iranian forests (Akhani et al., 2010) and it is more probable that the Qoroq ship was built in a Russian shipyard. Since the mid-18th century, the Caspian Sea was actually navigated mainly by Russian ships and Iranians were limited by Russia to build heavy ships (Bazin and Bromberger, 1982). Although little is known about Iranian ship architecture in the 18th century, this hypothesis is substantiated by the complex nature of the Qoroq shipwreck and its size. The heavy presence of European merchants in the Caspian
Sea from the 18th to the early 19th centuries (Curzon, 2007; Fraser, 1826; Hanway, 1762; Khodaverdi, 2008) and their permission to exploit and export wood from Talesh forests (Khodaverdi, 2008) suggest that the ship had being used for the trade between Talesh and Russian territories in 18th century. However, the claims about the origin of the ship, its construction methods and its exact use need further detailed studies.

With reference to the absence of any objects, it seems that the ship was emptied before sinking. Different scenarios could be considered for landing the ship in Qoroq coast, according to historical documents and/ or environmental changes. Regarding to the large hole in northern side of the hull and complete damage of the southern half of the ship (Fig. 5A and $\mathrm{E}$ ), it is reasonable to assume that it was part of the scuttling process e.g. damaging the ship during the Russia-Iran wars in early 19th century (Khodaverdi,2008). Another possible scenario for the ship's abandonment could be related to the 1904 law which stated that in Russia wooden ships were to be replaced by steamships (Nagdaliev, 1976).

The ship's age is coeval with the end of the Little Ice Age (LIA) era, when the Caspian sea-level was higher than today (Fig. 13) and the 

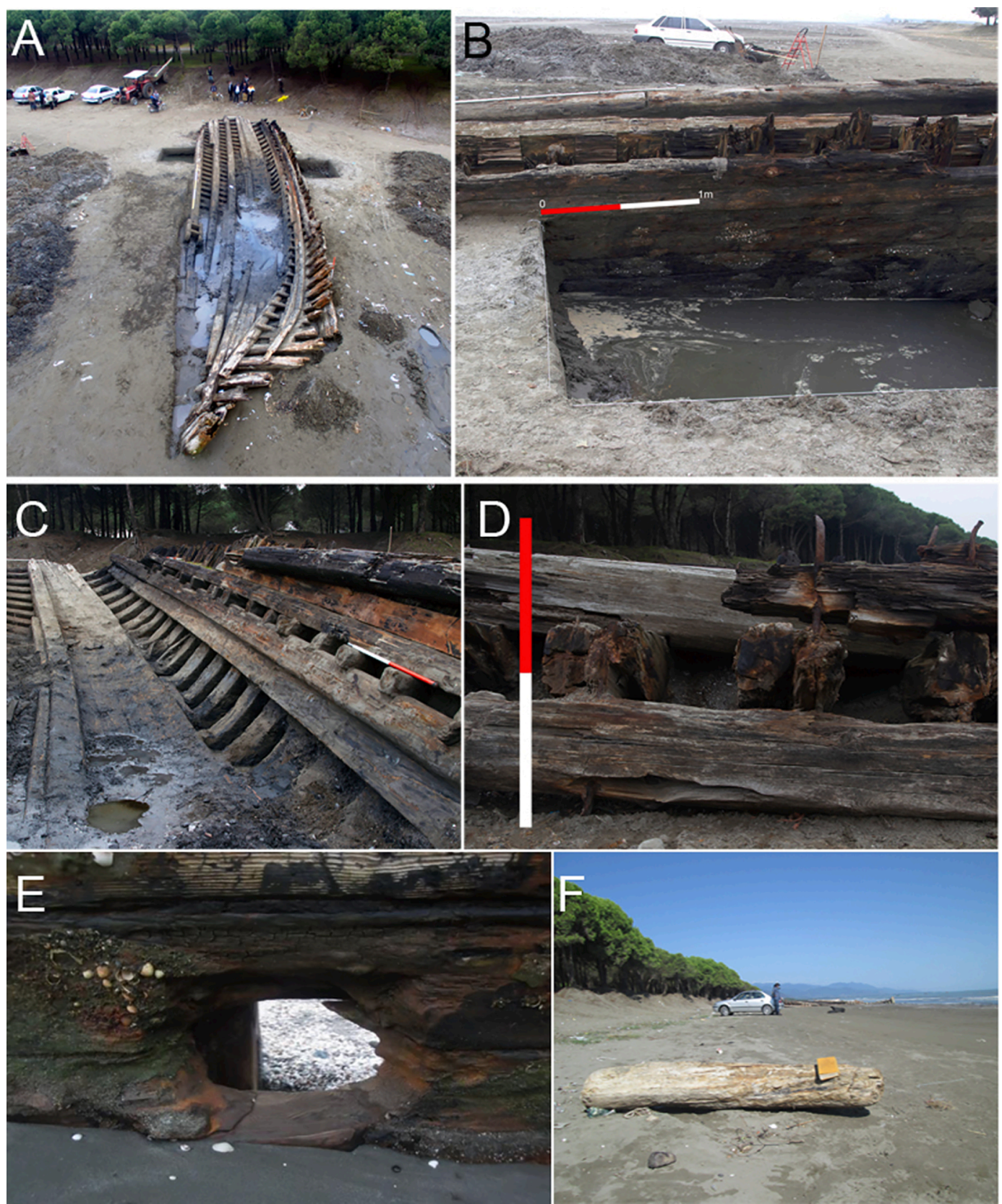

Fig. 5. The uncovered Qoroq Shipwreck: A) an aerial photo of the Qoroq Shipwreck that shows the ship has been broken into half along its longitudinal axis. B) The northern trench and the wooden planks of the hull. C) The frame of the shipwreck consisting of wooden beams that crossed and nailed to each other. D) Metal nails used in the ship to fix the structure. E) A large hole with a diameter of $40 \mathrm{~cm}$ located on the northern side of the ship where the wooden planks are present. F) A piece of wood, $50 \mathrm{~m}$ south of Qoroq shipwreck, that was detached from the ship by wave action in 2018.

region was being received higher precipitation (Leroy et al., 2011) and more intensive storms (Dezileau et al., 2011; Naderi Beni et al., 2013b). The hypothesis of higher storminess is also supported by higher strength of the Siberian High during the first half of the 19th century (D'Arrigo et al., 2005) which can directly control the intensity of northeasterly winds during the winter months (Alijani and Harman, 1985). Khodaverdi (2008) mentioned that many Russian ships in their ways to Anzali, were using the waters around Talesh waters as a sheletr during stormy conditions. It means that even in the 19th century, coastal sailing routes were prefered. Coastal sailing increased the risk of grounding by being driven ashore by squalls or running aground in shallow water due to rapid sea-level fall. Dramatic sea-level change in the early 19th century (Fig. 13) led to coastal waters becoming shallower, where previously was sailing by the ships easily. The grounding of ships in coastal waters were recorded in some historical documents (e.g. Fig. 3). It is beyond the scope of this paper to extend the research to the early 20th century when the use of wooden ships was banned by the Russian government (Nagdaliev, 1976). We conclude that, based on the evidence presented above, the maximum life span of the ship can be extended from the mid-18th century to the early 20th century (Fig. 13).

Whatever the reason for its sinking, the ship was situated in a high energy coastal environment where gravels were deposited inside the ship (Fig. 6). At present the ship lies on a sandy beach. Due to higher energy condition during the LIA, gravel was being deposited in coastal area of Guilan where that today is covered by sand (Naderi Beni et al., 2013b; Lahijani et al., 2009). Meanwhile, according to the outcrop and the test trenches (Figs. $4 \& 2$ ), it seems that gravel has not been deposited at the site for a long time. Therefore, it seems likely that the 


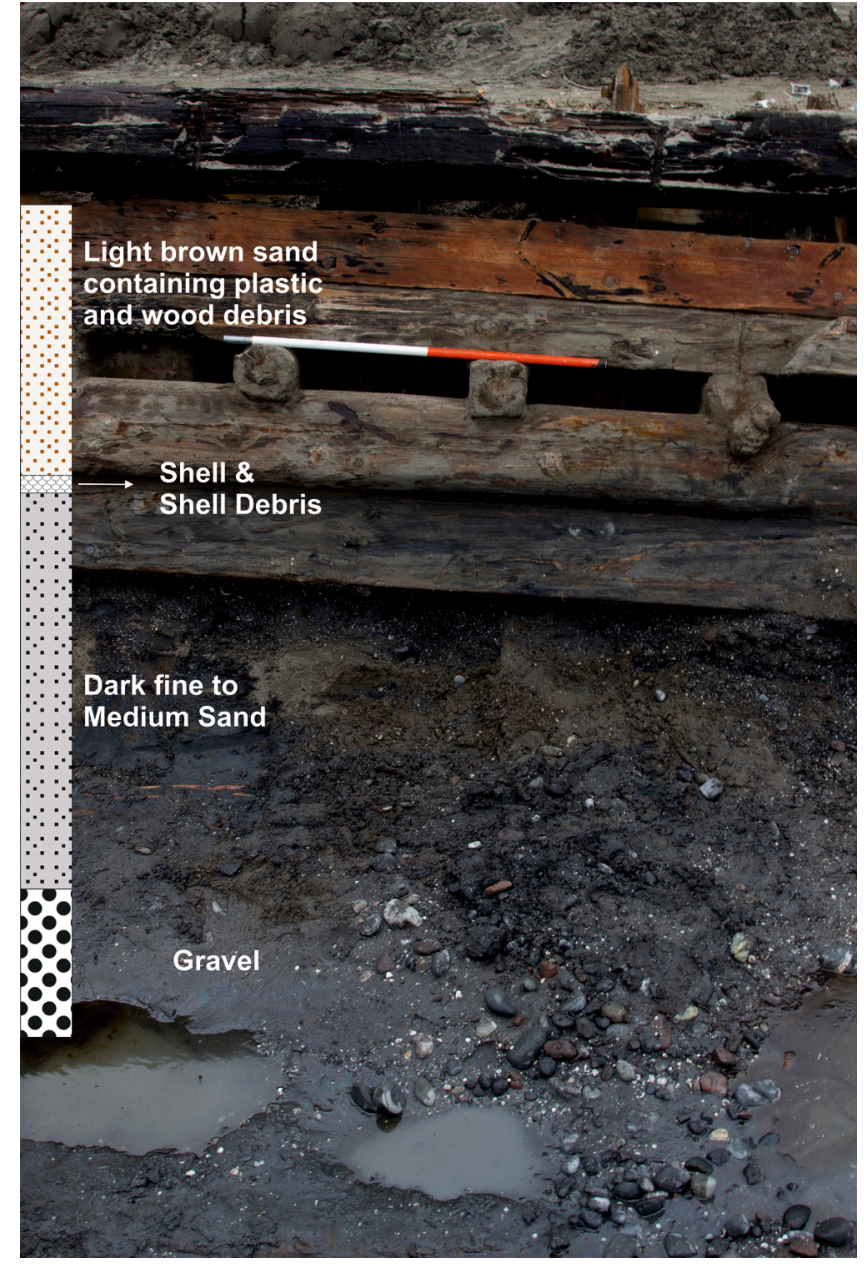

Fig. 6. Sediment layers inside the shipwreck. The ship floor is covered by a gravelly layer of approximately $30 \mathrm{~cm}$. It lies under a dark fine to medium-sized sand that is covered by a thin layer of shell and shell debris. The topmost layer consists of recently deposited medium sized brown sand.

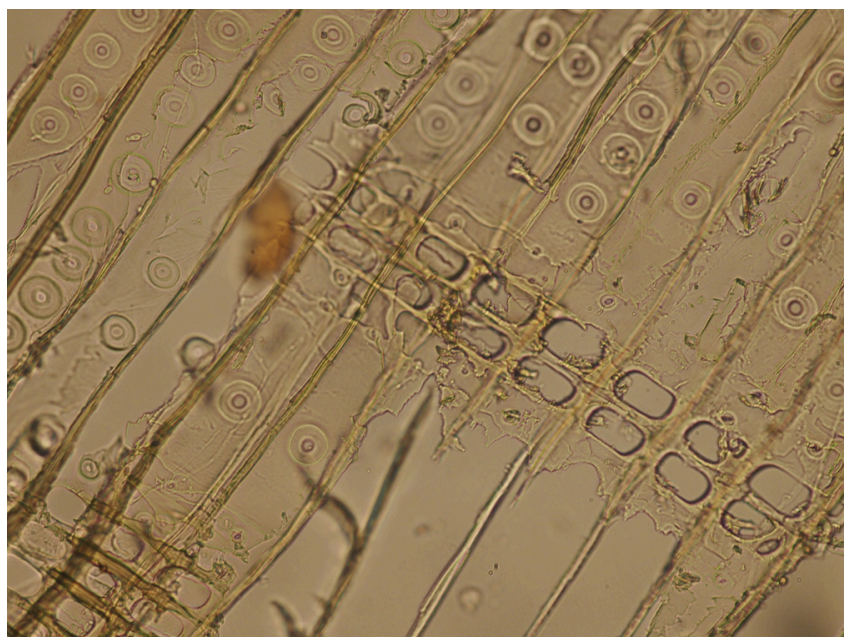

Fig. 7. Radial section of one wooden piece identified: Pinus type sylvestris.

ship has moved from a high energy environment to its current location. Shingle beaches with coarse grained materials are frequent in river mouths of the western coast of the Caspian Sea from Darband in Russia to Talesh in Iran. However, it is highly unlikely that the ship was

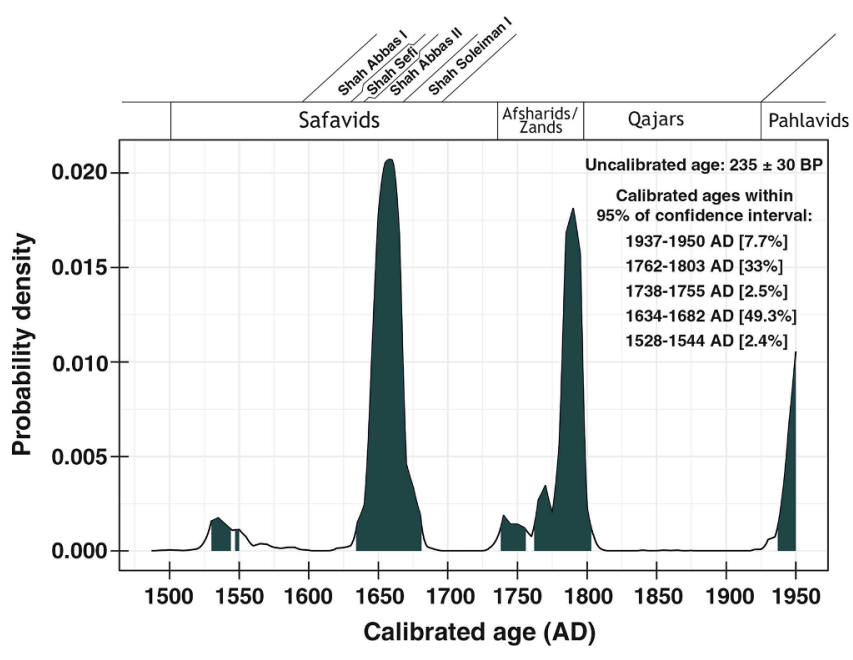

Fig. 8. Probability distribution curves of the calibrated radiocarbon age of Qoroq shipwreck wood sample. The calibrated age ranges with different probabilities (within brackets) based on 2-sigma range error, are also reported the highest probabilities are centered around 1660, 1780, and 1950 CE. The 1762-1803 range is retained here as the real age of the sample (see the text for our arguments).

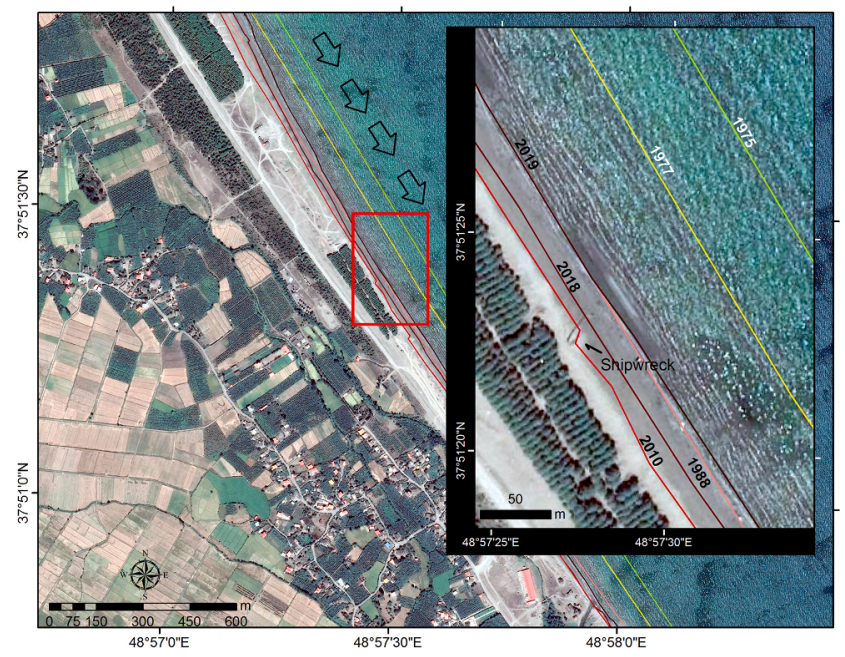

Fig. 9. Shoreline change analysis between 1975 and 2019 using different types of satellite images including Landsat series and high resolution images such as Ikonos, QuickBird, and WorldView-2. The black arrows show the direction of the prevailed long-shore currents in the study area.

dragged over long distances and deposited in its present position. Three rivers, Lisar (10 km to the north), Karganroud and Asalem, 3 and $10 \mathrm{~km}$ to the south, respectively, are the nearest rivers to the Qoroq shipwreck. According to the general current patterns of the Caspian Sea (Fig. 1) and predominant waves from the northeast (Rusu and Onea, 2013), the ship would be dragged southward from where the Lisar discharges into the sea (Fig. 14). This assumption is supported by different sediment types present inside and around the ship. Moreover, GPR data show that a southward distribution for the remains of the ship and that can be interpreted as resulting from the dominant wave and current direction.

In addition to the general hydrodynamic regime of the site, the other major determining factor in both the preservation and exposure of the ship could be attributed to the sea-level changes of the Caspian Sea. If the ship sunk during the wars of the early to mid-19th century, the sealevel was around 3 to $6 \mathrm{~m}$ higher than the present day (Fig. 13). In early 20th century, when sailing ships were gradually replaced by steamships, the sea-level was at least $2 \mathrm{~m}$ higher than today. Higher sea levels means 

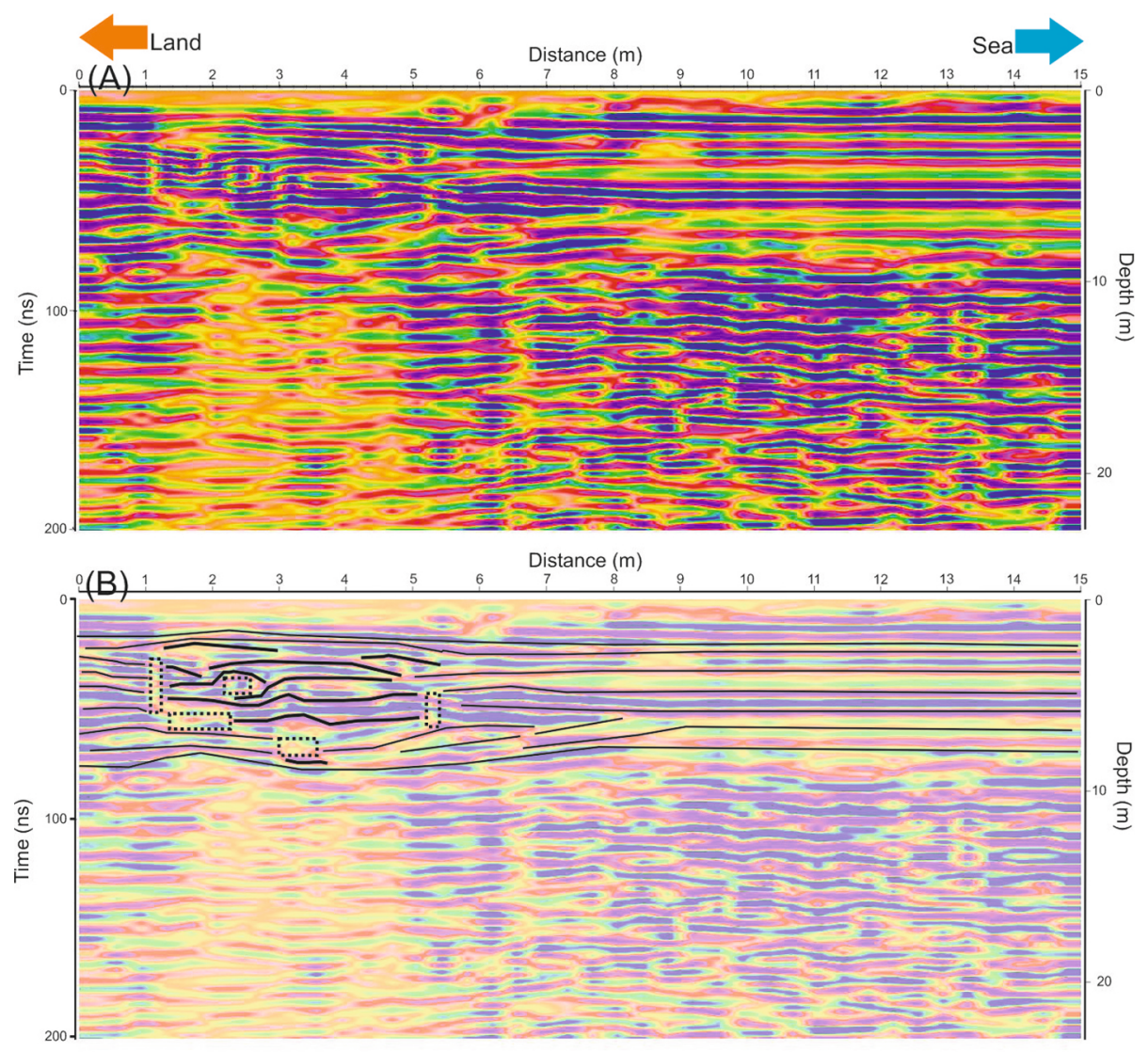

Fig. 10. A single GPR profile $30 \mathrm{~m}$ south of the Qoroq Shipwreck. A) The processed GPR profile show anomalies in the distance from $15.5 \mathrm{~m}$ from the starting point. The Seaward and landward directions are marked by arrows. B) The interpretation of the GPR profile resembles some solid objects in distances of 1 to $5.5 \mathrm{~m}$ that changed the sedimentation patterns.

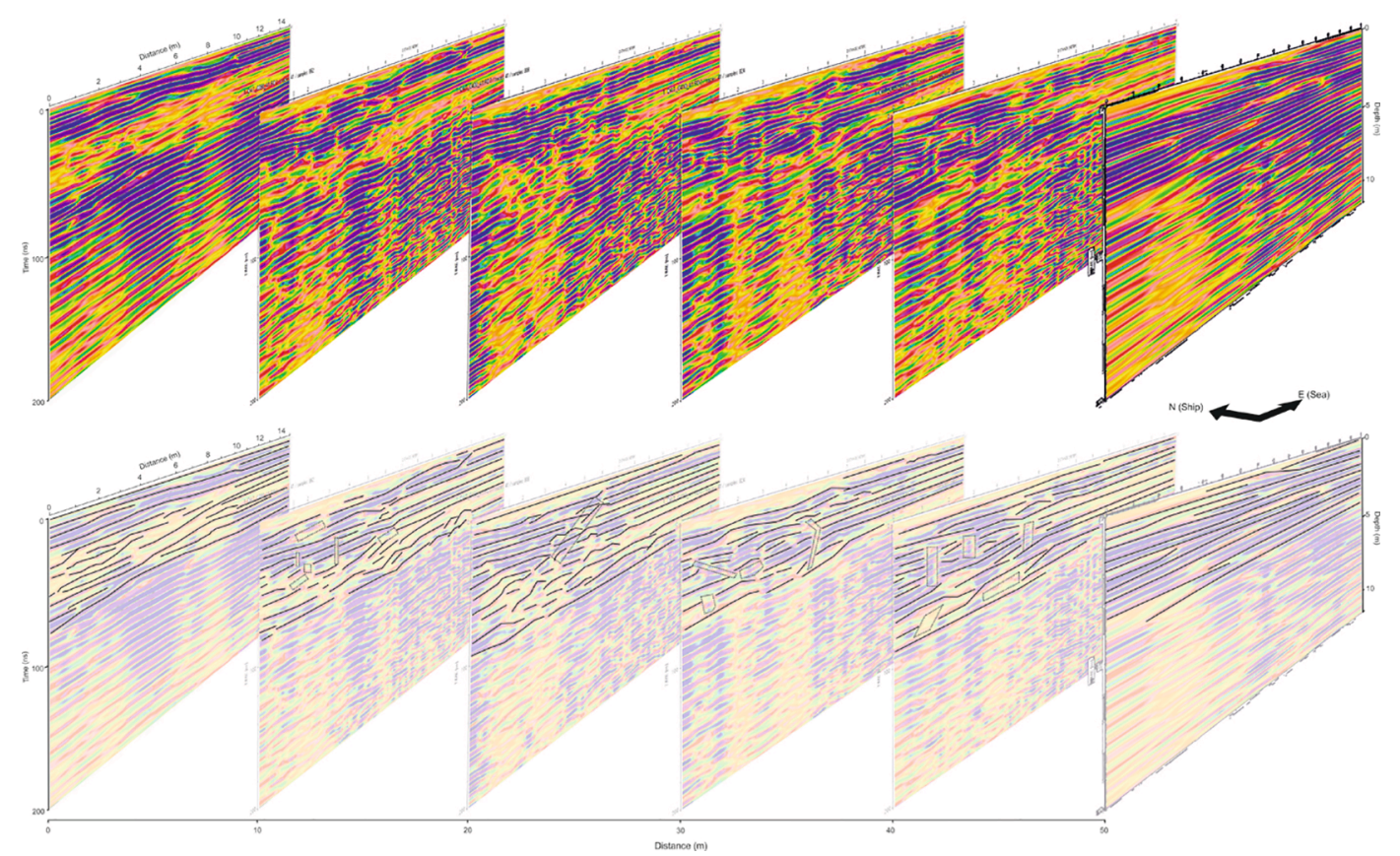

Fig. 11. The arrangement of 6 parallel GPR profiles south of the Qoroq Shipwreck with $10 \mathrm{~m}$ increments. The profile Numbers are indicated as P\#. The direction of the profiles are shown by arrows. A) The Processed GPR profiles. Apart from the first and the last profiles, other profiles show strong anomalies at depths of 3.5 to around $7 \mathrm{~m}$ and at the distance 1 to $5.5 \mathrm{~m}$ from the starting point. B) The interpretation of the GPR profiles. The black lines follow the direction of reflectors (sediment layers). It seems some solid objects changed the sedimentation patterns in profile 2 to 5 . 


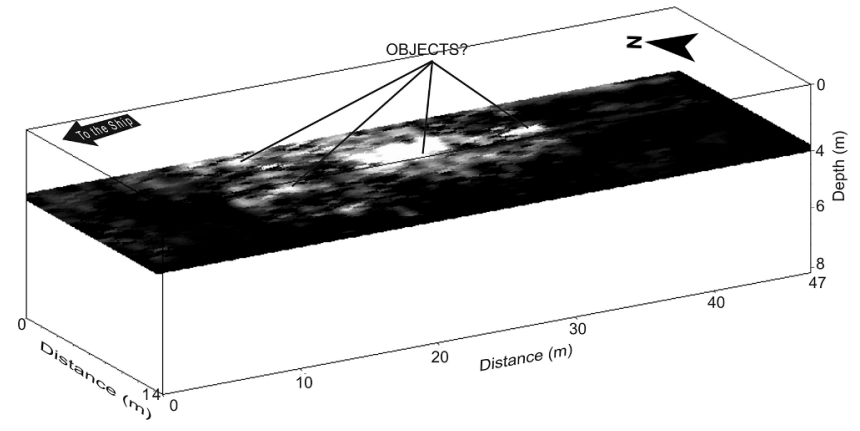

Fig. 12. A horizontal section of a 3D image of the subsurface using the GPR profiles in south of the Qoroq shipwreck. The image shows the existence of some strong anomalies at the depth of around $4 \mathrm{~m}$ which are distributed in an area of around $25 \mathrm{~m}$ in length and around $6 \mathrm{~m}$ in width. that ships could approach further inland and closer to the foothills where coarser grained materials are more available. Repeated sea-level fluctuations led to the deposition of different types of sediments inside the ship. In fact, the rapid sea-level rise of the Caspian Sea can shift coastal environments (e.g. lagoons) landward (Naderi Beni et al., 2014). The gray sand deposited over the gravel layer (Fig. 6) shows a relatively low energy environment with anoxic condition that could preserve wood samples over longer time (Kocabaş and Özsait Kocabaş, 2010). A lagoonal environment has been formed in coastal areas between Lisar and Karganroud deltas (Fig. 1). It therefore seems that the predominant hydrodynamic regime of the study area along with sea-level rise dragged the ship to an environment that was more favorable for its long-term preservation. While sea-level rise is more responsible for breaking down the ship, sea-level fall brought it to light (Fig. 14). The location of the large piece of the hull (Fig. 14) illustrates the impact of the rapid sealevel changes and wave action that led to detachment of the large piece, washing it away and putting it on top of the coastal escarpment during

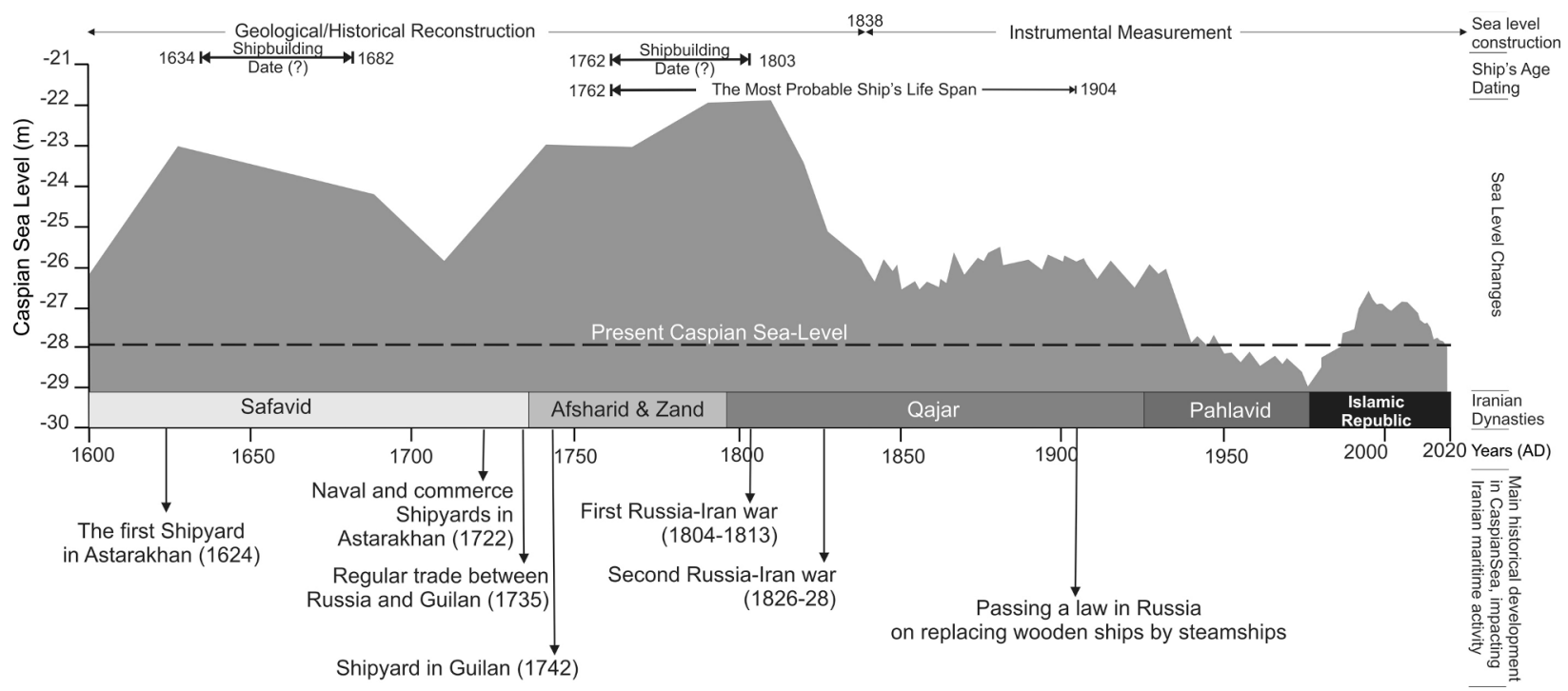

Fig. 13. The Caspian sea-level changes (Naderi Beni et al., 2013) and major maritime historical development that influenced the Iranian coast. The curve is a combination of historical and geological reconstructions of the sea-level with instrumental measurements. The present sea-level is illustrated by the dashed line. The results of calibrated age dates (Fig. 7) are marked in this figure by black rectangles. Consequent Iranian dynasties since the early 17th century are presented along the time axis of the curve. Major historical maritime development between Russia and Iran are determined by arrows in appropriate time.

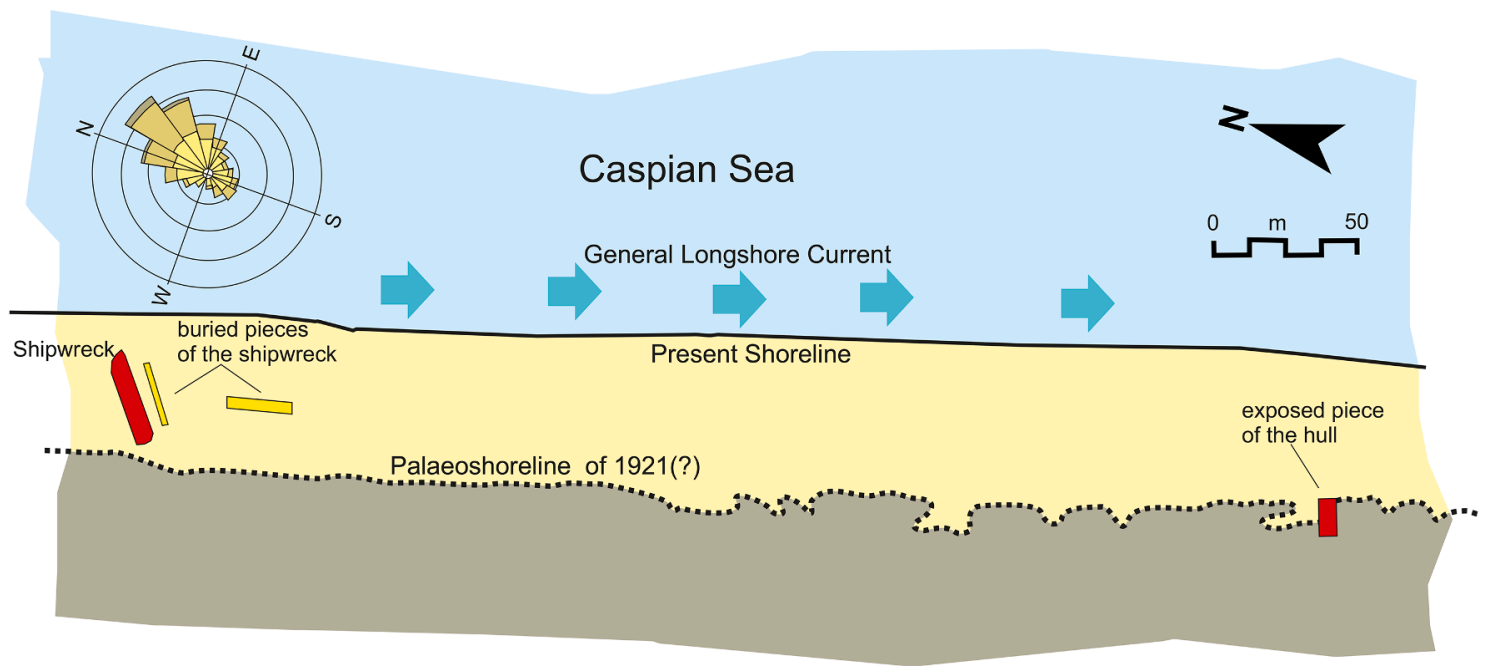

Fig. 14. A conceptual model of the impacts of hydrodynamic and sea-level changes on the shipwreck. The wind rose diagram is after Rusu and Onea (2013). The arrows show the direction of long shore currents according to predominant wind direction and the position of the coastline. Surface remains of the shipwreck are shown in red while buried remains detected by radar images are in yellow. 
storms. With this in mind it is therefore imperative to plan for the future preservation of this site.

\section{Conclusion}

The Qoroq shipwreck in southwest corner of the Caspian Sea has provided a good opportunity to review Caspian maritime history since the mid-18th century and the impacts of the Caspian environment on trade. This study also shows how historical, geological and archaeological studies could be jointly applied for revealing the past maritime issues of the Caspian Sea. Although different ages were suggested by radiocarbon dating, historical data supports the mid-18th century for constructing the ship. Moreover, historical and archaeological data suggest different man-made and/or environmental scenarios for the ship retirement. Geological data show that the sinking place of the ship and the exposing location of the ship are different. Geological data also show that environmental factors, especially the Caspian sea-level changes have pivotal role in preservation and exposing the ship. These environmental factors are working and could damage the shipwreck or deteriorate the preservation condition of the shipwreck. Immediate conservation plans are needed to save the Qoroq shipwreck.

\section{Acknowledgment}

This study was supported by the Ports and Maritime Administration of Guilan Province, Iran in the framework of the project No. 964/S11. Special thanks to Dr. Ahmad Ghaffarzadeh, the research manager of the Anzali Port, as well as Mehrdad Arbabian from Ports and Maritime Organization of Iran for their supports. The authors appreciate Dr. Joyanto Routh - Linköping University, Sweden for his support on radiocarbon age dating. INIOAS has provided instrumentation and logistics for this study. The authors appreciate the thoughtful comments of the paper's reviewers that helped us to improve the work.

\section{References}

Ahrari, H., 1996. A study of the evolution of the Caspian Sea's name. Caspian Sea Q, 2, 4-16.

Akhani, H., Djamali, M., Ghorbanalizadeh, A., Ramezani, E., 2010. Plant biodiversity of Hyrcanian relict forests, N Iran: an overview of the flora, vegetation, palaeoecology and conservation: Pakistan J. Botany 42(Special Issue), 231-258.

Alijani, B., Harman, J.R., 1985. Synoptic climatology of precipitation in Iran. Ann. Assoc. Am. Geogr. 75, 404-416.

Bagheri, H., 2017. Sedimentology and mineralogical characteristics of the coastal sediments in the southern part of the Caspian Sea (Iran). J. Mar. Sci. Technol. Res. 11 (4), 43-60.

Bazin, M., 1974. Le Tâlech et les Tâlech : ethnie et région dans le Nord-Ouest de l'Iran. bagf 51 (417), 161-170.

Bazin, M., Bromberger, C., 1982. Gilân et Âzarbâyjân oriental: cartes et documents ethnographiques, Editions Recherche sur les civilisations, v. 24.

Bennigsen, A., Berindei, M., 1979. Astrakhan et la politique des steppes nord pontiques (1587-1588). Harvard Ukrainian Stud. 3, 71-91.

Chaichian, M.A., 2014. Red Snake: The Great Wall of Gorgan. Empires and Walls, Brill, Iran, pp. 53-89.

Chepalyga, A.L., 2007. In: The Black Sea Flood Question: Changes in Coastline, Climate, and Human Settlement. Springer Netherlands, pp. 119-148. https://doi.org/ 10.1007/978-1-4020-5302-3_6.

Curci, J., 2006. The reburial of waterlogged archaeological wood in wet environments: Technical briefs in historical archaeology v. 1, 21-25.

Curzon, G.N., 2007. Russia in Central Asia in 1889. Read Books, London.

Danișman, Z., 1970. Çelebi Seyâhatnâmesi III, Istanbul.

D'Arrigo, R., Jacoby, G., Wilson, R., Panagiotopoulos, F., 2005. A reconstructed Siberian High index since A.D. 1599 from Eurasian and North American tree rings. Geophys. Res. Lett. 32, L05705.

Dezileau, L., Sabatier, P., Blanchemanche, P., Joly, B., Swingedouw, D., Cassou, C. Castaings, J., Martinez, P., Von Grafenstein, U., 2011. Intense storm activity during the Little Ice Age on the French Mediterranean coast. Palaeogeogr. Palaeoclimatol. Palaeoecol. 299 (1-2), 289-297.

Fraser, J.B., 1826. Travels and Adventures in the Persian Provinces on the Southern Banks of the Caspian Sea. (etc.), London, Longman.

Ghaffari, P., Chegini, V., 2010. Acoustic Doppler Current Profiler observations in the southern Caspian Sea: shelf currents and flow field off Feridoonkenar Bay, Iran: Ocean Sci. 6(3), 737

Gunduz, M., Özsoy, E., 2014. Modelling seasonal circulation and thermohaline structure of the Caspian Sea: Ocean Sci. 10(3).
Hanway, J., 1762. An Historical Account of the British Trade Over the Caspian Sea, with the Autor's Journal of Travels Through Russia Into Persia by Jonas Hanway, Dublin, Osborne.

Haslett, J., Parnell, A., 2008. A simple monotone process with application to radiocarbon-dated depth chronologies. J. R. Stat. Soc.: Ser. C (Appl. Stat.) 57 (4), 399-418.

Herzfeld, E., Walser, G., 1968. The Persian empire: studies in geography and ethnography of the Ancient Near East. Coronet Books Inc

Ibrayev, R., Özsoy, E., Schrum, C., and Sur, H., 2010. Seasonal variability of the Caspian Sea three-dimensional circulation, sea level and air-sea interaction: Ocean Sci. 6(1).

Jacquiot, C., 1955. Atlas d'anatomie des bois des conifères, 2 tomes. Centre technique du bois, Paris, p. 134.

Kasimov, N.S., Kasatenkova, M.S., Gennadiev, A.N., Lychagin, M.Y., 2012. Modern geochemical evolution of lagoon-marshy landscapes in the western Caspian Sea region. Eurasian Soil Sc. 45 (1), 1-11.

Khodaverdi, A., 2008. History of Talesh Khanates during Russian wars against Iran (written in 1814). Ministry of Foreign Affairs, Tehran.

Kocabaş, U., Özsait Kocabaş, I., 2010. Shipwrecks at the Theodosian Harbour: Publications de l'Institut Français d'Études Anatoliennes 20 (1), 109-127.

Kosarev, A. N., 2005. Physico-geographical conditions of the Caspian Sea. In: The Caspian Sea Environment, Springer, pp. 5-31.

Kroonenberg, S.B., Badyukova, E.N., Storms, J.E.A., Ignatov, E.I., Kasimov, N.S., 2000. A full sea-level cycle in 65years: barrier dynamics along Caspian shores. Sed. Geol. 134 (3-4), 257-274.

Lahijani, H.A.K., Naderi Beni, A., Tudryn, A., Hosseindoust, M., Habibi, P., Pourkerman, M., 2019. Unraveling extreme events from deep water cores of the south Caspian Sea. Quat. Int.

Lahijani, H.A.K., Leroy, S.A.G., Naderi Beni, A., Kazanci, N., Gürbüz, A., 2016. QuickLakeH: Rapidly changing large lakes and human response. Quat. Int.

Lahijani, H.A.K., Rahimpour-Bonab, H., Tavakoli, V., Hosseindoost, M., 2009. Evidence for late Holocene highstands in Central Guilan-East Mazanderan, South Caspian coast, Iran. Quat. Int. 197 (1), 55-71.

Leroy, S.A.G., Lahijani, H.A.K., Djamali, M., Naqinezhad, A., Moghadam, M.V., Arpe, K., Shah-Hosseini, M., Hosseindoust, M., Miller, C.S., Tavakoli, V., Habibi, P., Naderi Beni, M., 2011. Late Little Ice Age palaeoenvironmental records from the Anzali and Amirkola Lagoons (south Caspian Sea): Vegetation and sea level changes. Palaeogeogr. Palaeoclimatol. Palaeoecol. 302 (3-4), 415-434.

Maarleveld, T.J., Guérin, U., Egger, B., 2013. Manual for activities directed at underwater cultural heritage: Guidelines to the annex of the. Unesco. UNESCO 2001 convention.

McLean, P., 2019. Wood properties and uses of Scots pine in Britain. Forestry Commission Research Report, p. 36.

Naderi Beni, A., Alizadeh-Lahijani, H., Pourkerman, M., Jokar, R., Djamali, M., Marriner, N., Andrieu-Ponel, V., and Mousavi Harami, R., 2014. Late Holocene Caspian Sea Level Changes and its Impacts on Low Lying Coastal Evolution: a Multidisciplinary Case Study from South Southeastern Flank of the Caspian Sea. J. Persian Gulf 5(16), $27-48$.

Naderi Beni, A., Lahijani, H., Mousavi Harami, R., Arpe, K., Leroy, S., Marriner, N., Berberian, M., Andrieu-Ponel, V., Djamali, M., Mahboubi, A., 2013a. Caspian sealevel changes during the last millennium: historical and geological evidence from the south Caspian Sea. Clim. Past 9(4), 1645-1665.

Naderi Beni, A., Lahijani, H., Moussavi Harami, R., Leroy, S.A.G., Shah-Hosseini, M. Kabiri, K., Tavakoli, V., 2013. Development of spit-lagoon complexes in response to Little Ice Age rapid sea-level changes in the central Guilan coast, South Caspian Sea, Iran. Geomorphology 187, 11-26.

Nagdaliev, B., 1976. The history of the development of maritime shipping in the Caspian. In: Complex of Caspian Sea Studies, Moscow, pp. 274-278 (Russian).

Neal, A., Roberts, C.L., 2000. Applications of ground-penetrating radar (GPR) to sedimentological, geomorphological and geoarchaeological studies in coastal environments. Geol. Soc. Lond. Spec. Publ. 175 (1), 139-171.

Nokandeh, J., Sauer, E.W., Rekavandi, H.O., Wilkinson, T., Abbasi, G.A. Schweninger, J.-L., Mahmoudi, M., Parker, D., Fattahi, M., Usher-Wilson, L.S., Ershadi, M., Ratcliffe, J., Gale, R., 2006. Linear Barriers of Northern Iran: The Great Wall of Gorgan and the Wall of Tammishe. Iran 44 (1), 121-173.

Okorokov, A.V., 1993. Development of underwater archaeological investigations in Russia and the former Soviet Union. Int. J. Nautical Archaeol. 22 (3), 267-273.

Olearius, d A., 1656. Relation du Voyage de Moscovie, Tartarie et de Perse, Paris.

Rabino, H.L., 1917. Les provinces caspiennes de la Perse: Le Guîlân. E. Leroux, Paris.

Reimer, P.J., Bard, E., Bayliss, A., Beck, J.W., Blackwell, P.G., Ramsey, C.B., Buck, C.E., Cheng, H., Edwards, R.L., Friedrich, M., Grootes, P.M., Guilderson, T.P., Haflidason, H., Hajdas, I., Hatté, C., Heaton, T.J., Hoffmann, D.L., Hogg, A.G., Hughen, K.A., Kaiser, K.F., Kromer, B., Manning, S.W., Niu, M.u., Reimer, R.W., Richards, D.A., Scott, E.M., Southon, J.R., Staff, R.A., Turney, C.S.M., van der Plicht, J., 2013. IntCal13 and Marine13 Radiocarbon Age Calibration Curves 0-50,000 Years cal BP. Radiocarbon 55, 1869-1887.

Roberts, S.E., 1965. The Myth of Sten'ka Razin, Soviet Historical Drama, Springer, pp. $46-75$

RStudio Team, 2015. RStudio: Integrated Development for R. RStudio Inc, Boston, MA http://www.rstudio.com/.

Rusu, E., Onea, F., 2013. Evaluation of the wind and wave energy along the Caspian Sea. Energy 50, 1-14.

Schweingruber, F.H., 1982. Mikroskopische Holzanatomie, Anatomie microscopique des bois, Microscopic wood anatomy, F. Flück-Wirth, Internationale Buchhandlung für Botanik und Naturwissenschaften, Teufen, 2nd ed., p. 226.

Schweingruber, F.H., 1990. Anatomie europäischer Hölzer, Anatomy of European woods. Haupt, Bern und Stuttgart, p. 800. 
Stepanov, I., 1957. Peasants War led by S. T. Razin, Moscow (Russian).

Tarn, W.W., 2010. The Greeks in Bactria and India, Cambridge University Press.

Terziev, S., 1992, Hydrometeorology and hydrochemistry of seas. Vol. 6, the Caspian Sea, No 1. Hydrometeorological Conditions: Leningrad: Gidrometeoizdat (in Russian).
Tofighian, H., Adibi, R., 2017. Boat and ship Archaeology in Gilan Province (Iran). In Proceedings 3rd Asia-Pacific Regional Conference on Underwater Cultural Heritage, Hong Kong, 27 Nov.-2 Dec. 2017, vol. 1, Themua, pp. 321-342.

Tuzhilkin, V.S., Katunin, D.N., Nalbandov, Y.R., 2005. Natural chemistry of Caspian Sea waters. In: The Caspian Sea Environment, Springer, pp. 83-108. 